\title{
Скрайбирование кремниевых приборных пластин лазерным излучением в водной среде
}

\author{
А.Р. Новоселов \\ Новосибирский филиал Института физики полупроводников им. А.В. Ржанова СО РАН \\ «Конструкторско-технологический институт прикладной микроэлектроники», 630090, г. \\ Новосибирск, ул. Николаева, 8 \\ E-mail:novoselov@oesd.ru
}

DOI 10.34077/RCSP2021-154

Исследовано воздействие процесса скрайбирования лазерным излучением в водной среде на кремниевые СБИС, применяемые в гибридных фотоприёмниках инфракрасного излучения.

Особенностью лазерного скрайбирования в водной среде является быстрое охлаждение расплава водой и, как результат, полное отсутствие расплава в канавке и на поверхности приборной пластины.

На рисунке представлена РЭМфотография края флип-чип фотоприёмника для демонстрации полного отсутствия расплава на поверхности и стенках канавки. На фотографии видны края алюминиевых контактных площадок под индиевыми столбами, изолирующие слои диоксида кремния и алюминиевая токопроводящая дорожка. Однако при этом значительно расширяется область, где повреждаются p-n переходы. В этой области измененяется напряжение начала

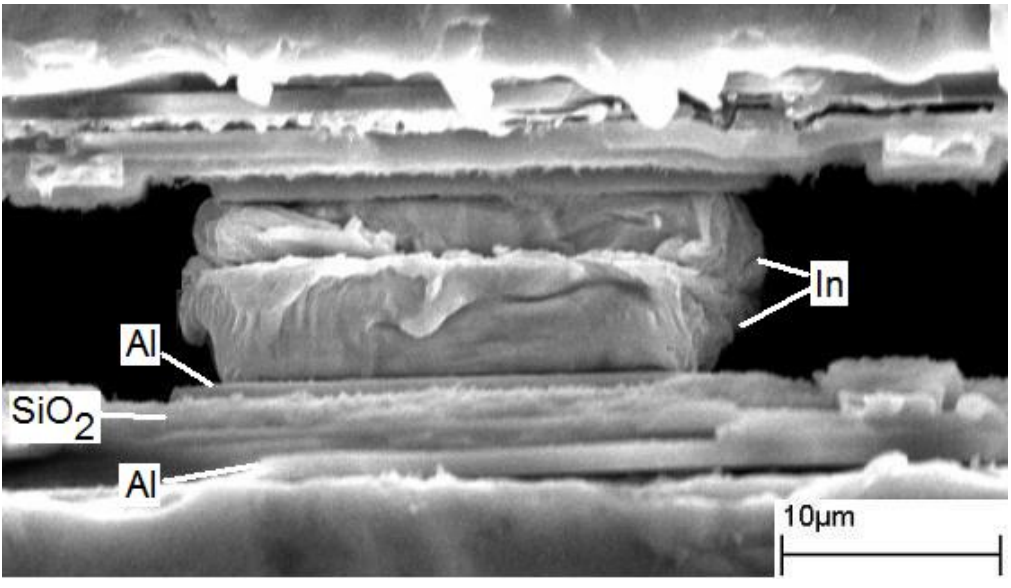
пробоя p-n перехода Уменьшение напряжения начало пробоя связано с возникновением, так называемой области «мягкого» пробоя n-p переходов. При скрайбировании кремниевых СБИС в водной среде в сравнении с результатами скрайбирования на воздухе зона повреждения увеличивается с 13 до 47 мкм; на расстояниях до 40 мкм от края канавки во время лазерного скрайбирования в водной среде давление воды на образец составляет не менее $1,5 \times 10^{-6}$ кг/мкм ${ }^{2}$, что достаточно для деформации индиевого столба на поверхности кремниевого мультиплексора (кремниевая СБИС). 